\title{
INTEGRATION COSTS OF RENEWABLE ENERGY TECHNOLOGIES IN FUTURE ENERGY GENERATION SCENARIOS
}

\author{
M.D. Sklar-Chik ${ }^{1,2 *}$, A.C. Brent ${ }^{2,3} \&$ I.H de Kock ${ }^{2}$
}

\section{ARTICLE INFO}

\section{Article details}

Submitted by authors 9 Jul 2017

Accepted for publication 14Jun 2018

Available online $\quad 31$ Aug 2018

\section{Contact details}

mark.sklar.chik@gmail.com

\section{Author affiliations}

1 Energy Exemplar LLC

2 Department of Industrial Engineering, and the Centre for Renewable and Sustainable Energy Studies, Stellenbosch University, South Africa

3 Sustainable Energy Systems, School of Engineering and Computer Science, Victoria University of Wellington, New Zealand

DOI

http: //dx.doi.org/10.7166/29-2-1801

\section{ABSTRACT}

The objective of the paper is to understand the integration costs of renewable energy technologies (RETs) in future energy generation scenarios for South Africa. The study used PLEXOS ${ }^{1}$ to conduct a bottom-up hourly simulation, incorporating the high renewable energy scenarios of the World Wildlife Fund (WWF) for 2030, in which RET penetrations are projected to be below 20 per cent. After verification and validation of the model by PLEXOS subject matter experts, the final model was run with two cases: a base case, and a constraint case. The results for these two cases for the year 2030 exhibited system costs of R0.39/kWh and R0.48/kWh respectively. A secondary output was the levelised cost of energy values for a number of energy generation technologies. A sensitivity analysis subsequently revealed that the largest contributor to a change in system costs is the demand forecast, followed by an increase in renewable energy outputs. Finally, recommendations are made to improve future energy modelling research by addressing the key assumptions of this research inquiry.

\section{OPSOMMING}

Die doel van hierdie artikel is om die integrasie kostes van hernubare energie tegnologieë (HETs) met toekomstige energieopwekkingscenario's vir Suid Afrika te ondersoek. 'n PLEXOS ${ }^{1}$ model is gebruik om die World Wildlife Fund (WWF) se hoë hernubare energie scenario vir 2030, waar HET se netwerk-penetrasie vlakke voorspel word om minder as 20 persent te wees, te simuleer. $\mathrm{Na}$ verifikasie en validasie van die ontwikkelde PLEXOS ${ }^{1}$ model met verskeie kundiges, het die finale iterasie met twee gevalle vorendag gekom, naamlik ' $n$ basis-geval en 'n beperkte-geval. Die resultate van hierdie twee scenario's vir die jaar 2030 is stelselkostes van onderskeidelik R0.39/kWh en R0.48/kWh. 'n Sekondêre uitset was die gelykgestelde koste van energie waardes vir van die energie opwekkingstegnologieë. Daarna is 'n sensitiwiteitsanalise gedoen om te bepaal wat die grootste bydraende faktor tot verandering in stelselkostes en die aanvraagsvoorspelling is. Laastens is aanbevelings gemaak oor hoe om toekomstige modellerings uitkomstes in hierdie area van navorsing te verbeter deur die sleutel aannames van so 'n navorsingsvoorstel aan te spreek.

\section{INTRODUCTION}

The South African electricity landscape has seen significant changes over the last decade. One major impact has been the introduction of renewable energy technologies (RETs) on a utility-scale level, through the Renewable Energy Independent Power Producers Procurement Programme (REIPPPP2).

1 An energy market simulation tool offering short- to long-term time horizon studies. Provided by Energy

Exemplar.

2 https://www.ipp-renewables.co.za/ 
As a result of this programme, the electricity sector has seen a decrease in the price of renewable energy, with wind and solar photovoltaic (PV) reaching near grid parity $[1,2]$. Even though RETs are becoming less expensive and cost-competitive than traditional base load technologies, gaps still exist in understanding the integration of RETs into the electricity system. Furthermore, the future electricity system will have to deal with these non-dispatchable technologies ${ }^{3}$ and related inherent integration costs. To this end, the current vertically integrated nature of the industry will need to scrutinise the integration costs of renewables within the electricity system.

The electricity sector commonly uses the levelised cost of energy (LCOE) metric. While it is useful, there are hidden non-production-related costs for integrating RETs into the electricity sector [3]. The objective of this paper is thus to understand the real system costs of integrating renewable energy generation technologies into the South African electricity system in future scenarios. As part of the research, when calculating system costs, LCOEs for each of the following different technologies had to be ascertained to aid the comparison of their corresponding costs:

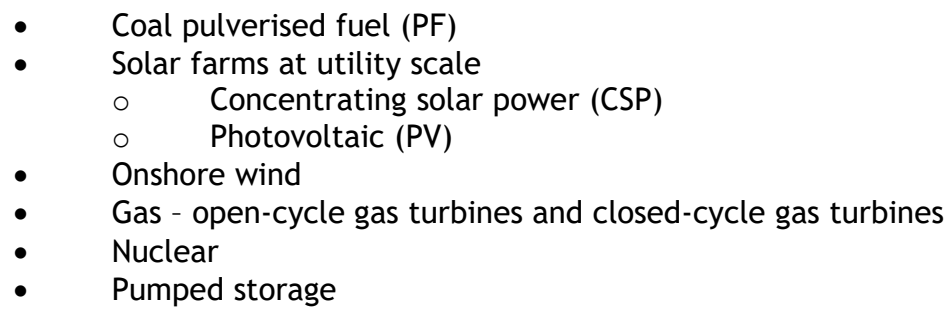

Small-scale projects (less than 100MW) were not included, as it was assumed that the South African government and Eskom would select reliable and mature technologies that will provide large-scale electricity to an established grid network, and hence will not consider such 'small-scale projects'. This study, however, takes a holistic approach and focuses on the national electricity system, which is primarily impacted by utility-scale projects; and the means of quantifying embedded generation in South Africa is unclear at this stage. Larger projects are more clearly accounted for in policy documents in the public domain. In addition, the research did not consider the detailed roadmap to achieve certain future energy targets; it looked at a specific future year, when targets (of renewable penetration) are achieved.

The research strategy entailed a structured approach that involved a number of steps, as shown in Figure 1. First, the research objective that guided the research process was described. The second step entailed a literature analysis, with the aim of understanding what has been addressed in previously completed research relating specifically to the costs associated with integrating renewables into the electricity system. Subsequently, the third step included obtaining the required input data and developing the model, which was termed 'the system model'. Lastly, the outputs from the system model were obtained and analysed. Throughout the research inquiry, continuous feedback was provided, ensuring that an iterative approach was followed. The system costs of generating electricity were investigated by conducting the research.

\section{LITERATURE REVIEW}

The literature review followed a semi-structured conceptual approach by describing the critical areas and concepts in a distinct narrative. The details are captured in Sklar-Chik, Brent and de Kock [3], and summarised in Figure 2.

A number of integration costs were uncovered in the literature of different authors [5,6,7], and are explained in detail by Sklar-Chik [4]. Generation technology costs are well-researched in the literature, are well-known in organisations, and are published yearly by large international bodies such as the International Energy Agency, among others. One such study, by Gauché [8], published the generation technology costs shown in Figure 3, and included technology-specific operating parameters and how they relate to these generation technology costs.

Dispatchable technologies are dependent on a fuel source (i.e., coal, nuclear, or gas). Non-dispatchable technologies' energy resources are wind, solar, or other variable resources. 


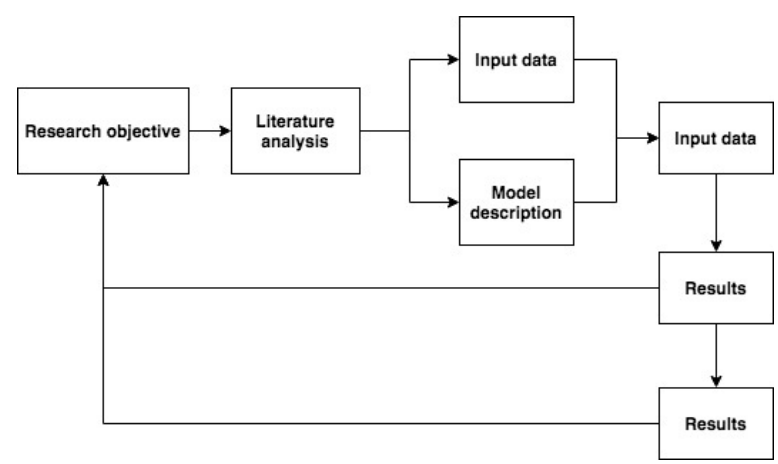

Figure 1: Research strategy

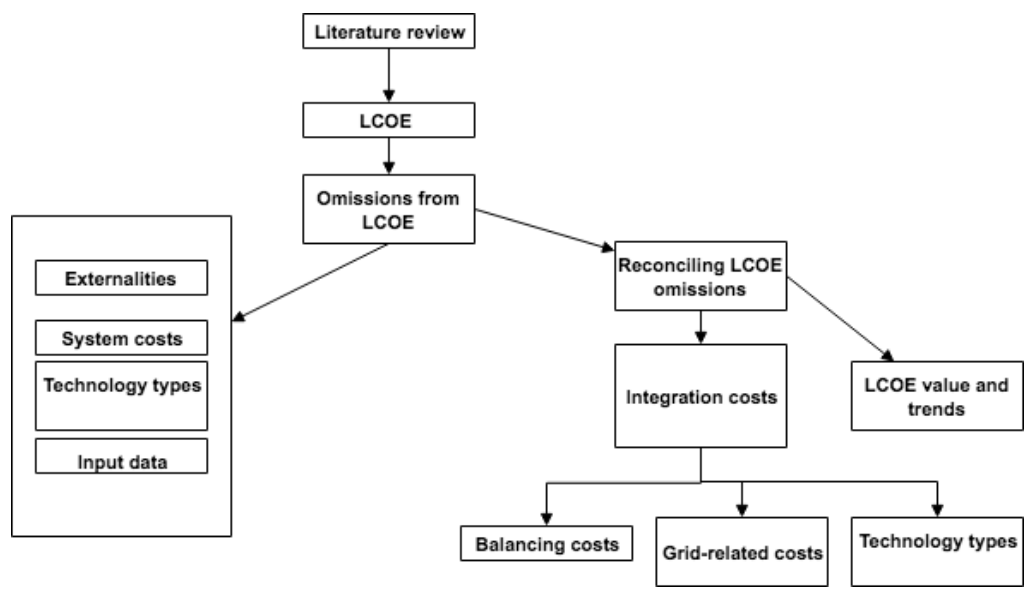

Figure 2: Literature review map [4]

\begin{tabular}{|c|c|c|c|c|c|c|c|c|c|}
\hline Technology & Range & $\begin{array}{l}\text { CAPEX } \\
(\mathrm{R} / \mathrm{kW})\end{array}$ & $\begin{array}{l}\text { Fixed Opex } \\
\text { (R/kW/a) }\end{array}$ & $\begin{array}{l}\text { Variable } \\
\text { Opex } \\
\text { (R/MWh) }\end{array}$ & $\begin{array}{l}\text { Fuel Costs } \\
\text { (R/GJ) }\end{array}$ & Availability & $\begin{array}{l}\text { Turn-down } \\
\text { limit }\end{array}$ & $\begin{array}{l}\text { Ramp rate } \\
(\% / \mathrm{min})\end{array}$ & $\begin{array}{l}\text { Maximum } \\
\text { life span }\end{array}$ \\
\hline \multirow[b]{2}{*}{ PV Fixed Tilt } & Upper & 13115 & 484 & $\begin{array}{l}0 \\
\end{array}$ & 0 & \multirow[b]{2}{*}{$90 \%$} & \multirow[b]{2}{*}{ NA } & & \multirow[b]{2}{*}{25} \\
\hline & Lower & 11210 & 208 & 0 & 0 & & & & \\
\hline \multirow[b]{2}{*}{ CSP - 6h TES } & Upper & 37610 & 573 & 29 & 0 & \multirow[b]{2}{*}{$90 \%$} & \multirow[b]{2}{*}{0} & \multirow[b]{2}{*}{$6 \%$} & \multirow[b]{2}{*}{30} \\
\hline & Lower & 36726 & 573 & 0 & 0 & & & & \\
\hline \multirow[b]{2}{*}{ CSP - 9h TES } & Upper & 43259 & 573 & 29 & 0 & \multirow[b]{2}{*}{$90 \%$} & \multirow[b]{2}{*}{0} & \multirow[b]{2}{*}{$6 \%$} & \multirow[b]{2}{*}{30} \\
\hline & Lower & 42242 & 573 & 0 & 0 & & & & \\
\hline \multirow[b]{2}{*}{ Wind } & Upper & 19463 & 400 & 0 & 0 & \multirow[b]{2}{*}{$90 \%$} & \multirow[b]{2}{*}{ NA } & & \multirow[b]{2}{*}{20} \\
\hline & Lower & 14502 & 310 & 0 & 0 & & & & \\
\hline \multirow[b]{2}{*}{ OCGT } & Upper & 5738 & 78 & 0,2 & 500 & \multirow[b]{2}{*}{$90 \%$} & \multirow[b]{2}{*}{0} & \multirow[b]{2}{*}{$22,50 \%$} & \multirow[b]{2}{*}{30} \\
\hline & Lower & 5615 & 78 & 0,2 & 92 & & & & \\
\hline \multirow[b]{2}{*}{ CCGT } & Upper & 8708 & 163 & 0,7 & 92 & \multirow[b]{2}{*}{$90 \%$} & \multirow[b]{2}{*}{0} & \multirow[b]{2}{*}{$5 \%$} & \multirow[b]{2}{*}{30} \\
\hline & Lower & 8524 & 163 & 0,7 & 70 & & & & \\
\hline \multirow[b]{2}{*}{ Nuclear } & Upper & 87754 & 1017 & 29,5 & 10 & \multirow[b]{2}{*}{$90 \%$} & \multirow[b]{2}{*}{0,8} & \multirow[b]{2}{*}{$5 \%$} & \multirow[b]{2}{*}{60} \\
\hline & Lower & 60000 & 532 & 29,5 & 6,8 & & & & \\
\hline & Upper & 34938 & 532 & 79,8 & $22-35$ & & & & \\
\hline Coal (PF with FGD) & Lower & 34894 & 368 & 51,2 & 17,6 & $80-85 \%$ & 0,4 & $2 \%$ & 60 \\
\hline & Upper & 56846 & 333 & 0 & 0 & & & & \\
\hline Pumped Storage & Lower & 23973 & 247 & 0 & 0 & $90 \%$ & 0 & $50 \%$ & 60 \\
\hline & Upper & 28341 & 344 & 13,9 & 0 & & & & \\
\hline Imported Hydro & Lower & 12044 & 80,2 & 0 & 0 & $66,7 \%$ & 0 & $2 \%$ & 60 \\
\hline & Upper & 28341 & 344 & 13,9 & 0 & & & & \\
\hline Domestic Hydro & Lower & 12044 & 80,2 & 0 & 0 & $96,6 \%$ & 0 & $2 \%$ & 60 \\
\hline
\end{tabular}

Figure 3: Costing inputs [8] 
Given that the research objective considers costs over a period of time, the analysis tool or approach selected was simulation, which provides a future-focused approach. To include the relevant technical detail, a bottom-up approach was taken. Connolly, Lund, Mathiesen and Leahy [9] reviewed 37 of the available energy modelling tools. Using the study conducted by Connolly et al. [9], PLEXOS was deemed the most suitable for this research inquiry from an application perspective; it was also accessible, as Eskom uses the tool for energy planning. Furthermore, PLEXOS provides for short-term production modelling with an hourly time-step size, and affords bottom-up simulation modelling. The year 2030 was selected because energy scenarios in the Department of Energy's Integrated Resource Plan for Electricity [10] and the WWF [1] set specific renewable targets for 2030. Finally, data was available from Eskom for hourly demand. Thus the simulation was run hourly for the year 2030.

The PLEXOS electricity market-modelling tool uses mathematical optimisation to address numerous electricity sector-related challenges. The software uses four modules, each of which addresses different time-scaled problems:

1) Long-term (LT) optimal investment module

a. Optimises generation and transmission network to minimise the net present value of the total system costs;

b. Builds and retires generation and transmission assets; and

c. Has a 10- to 30-year time horizon.

2) PASA optimal maintenance scheduling module:

a. Schedules maintenance for short and medium terms;

b. Includes outages; and

c. Computes reliability statistics (e.g., optimal reserve levels).

3) Medium-term (MT) decomposition module

a. $\quad$ Fast results for MT studies;

b. Optimises constraints;

c. Reduces simulation period into blocks (load duration curves); and

d. Breaks down MT constraints.

4) Short-term (ST) chronological module:

a. Mixed integer programming based chronological optimisation in each ST period;

b. Emulates real market clearing-engines; and

c. Can model competitive behaviour of actors (e.g., Nash-Cournot equilibrium).

The PLEXOS software also integrates all of the simulation phases, enabling analysis when long-term decisions can influence short-term plant operations. Addressing each timescale-specific challenge is one dimension of the problem; however, integrating solutions across the different timescales is a notable strength of PLEXOS.

\subsection{WWF high renewable energy scenario}

To address the stated research objective, the WWF high scenario [1] was selected, as this had the highest penetration of RETs. In this scenario, a number of base cases were selected. The base case using unconstrained generators was selected first, where no limits were imposed. Then a constrained case was produced, where the generators' real constraints were added, including minimum stable level (MSL), ramping constraints $(\mathrm{MW} / \mathrm{min})$, and emissions (tonnes $\mathrm{CO}_{2}$ ). Lastly, a sensitivity analysis was undertaken to test the model's sensitivity to a change in the input parameters. Cases for the sensitivity analysis included fuel prices at upper and lower levels (R/GJ), generator unit availabilities of 70 and 80 per cent (in line with Eskom 80:10:10 availability strategy), and an energy demand decrease to the WWF 'low level' [1]. All of the scenarios described above are shown in Figure 4, which highlights the key parameters that differ among the scenarios.

The developed model was validated by a corporate specialist for energy planning at a large utility and an energy modelling engineer at a large SA research institution, both through workshops at which the model was presented and discussed in detail. The system LCOE was calculated according to Gauche [8], where the electricity produced is added to the unserved energy and then divided by the annual system demand as follows:

$$
\text { System } L C O E=\frac{\left(\sum(L C O E * \text { Annual power }) \text { plant }+ \text { COUE } * \text { Annual unserved electricity }\right)}{\text { Annual system demand }}
$$




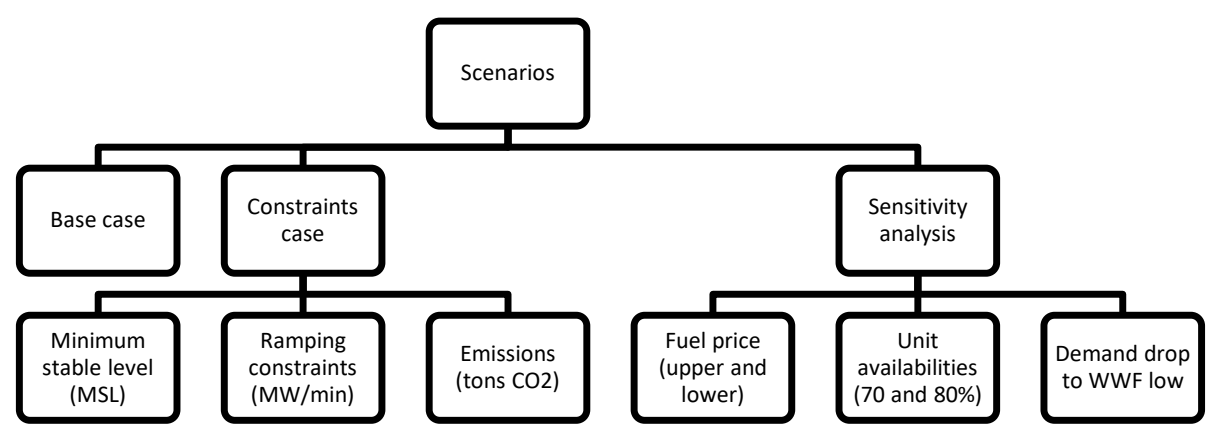

Figure 4: Scenario tree (Sklar-Chik, 2017)

\subsection{Model inputs}

As discussed above, the technology-specific input data was used for each generator, and the hourly load for 2010 was used as a basis load for each scenario. Initially, the 2010 load was compared against the 2015 load data; it was found that there was no significant increase in the energy load profile when comparing the data from 2010 and 2015. Figure 5 shows a load duration curve comparison of the 2010 and 2015 system demand, in which their profiles are correlated. Further analysis of the input demand profiles was performed by Sklar-Chik [4].

The 2010 load was thus used to forecast the system demand for 2015, using the multipliers proposed by DoE [10] and WWF [11]. Capex was calculated independently from the PLEXOS model, as this was not dependent on any simulation modelling (refer to Sklar-Chik [4] for a full account of the calculations and discussion of the Capex calculations). Further assumptions of the developed PLEXOS model included:

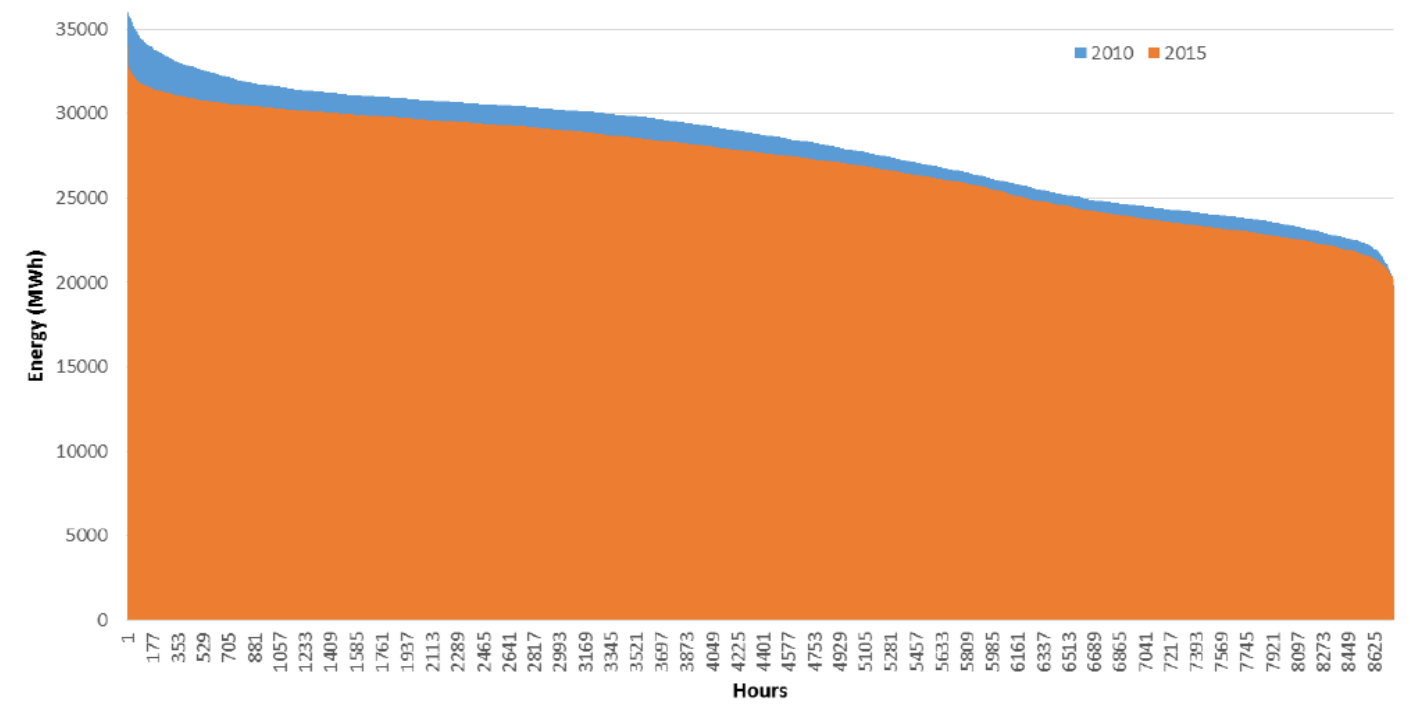

Figure 5: LDC for 2010 vs 2015 (system demand data) [4]

- $\quad$ using the WWF high- and low-demand scenarios;

- $\quad$ a decommissioning schedule for the existing plant as per DoE [10];

- $\quad$ the new build for 2030 according to the WWF scenarios [1];

- demand that was realised at a single node, and thus no grid infrastructure was included in the model (see Figure 6);

- $\quad$ all generators injecting energy into the single node (see Figure 6);

- $\quad$ the demand being realised at the node, and thus no grid considered; and

- $\quad$ the cost of unserved energy as per DoE [10].

The section above describes the model input values and important assumptions. 


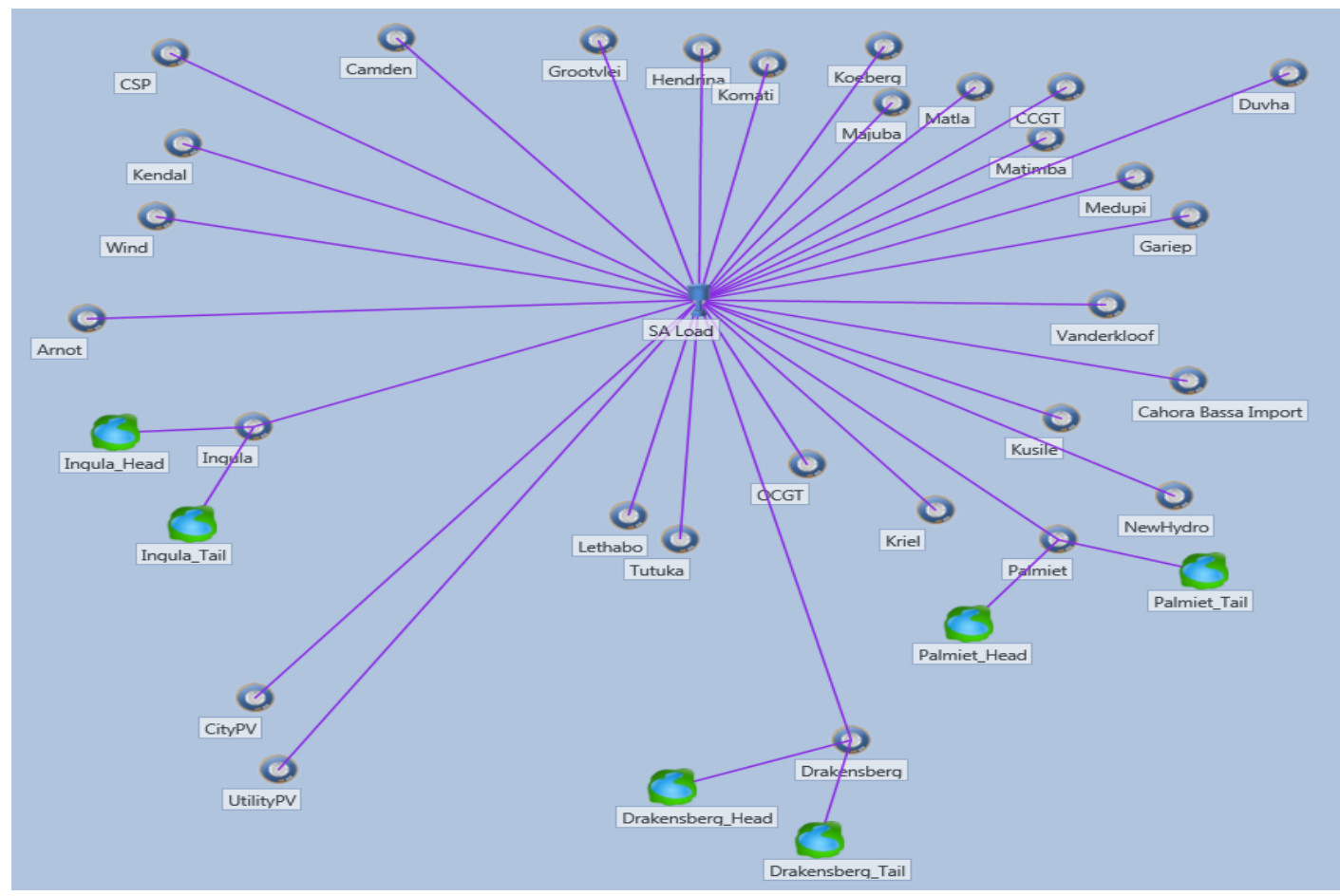

Figure 6: PLEXOS single node model [4]

\subsection{Verification using the WWF low renewable energy scenario}

The major difference between the WWF [9] study and the model in question was the 'day-ahead dispatch capability' of PLEXOS. The WWF study was performed in Excel, and so it did not have the day-ahead dispatch and forecasting functionality. The overall results of the PLEXOS WWF low and the WWF low model can be seen in Table 1. These were PLEXOS models using the WWF low model as a basis for each PLEXOS model, and they were considered at the lower and upper bounds.

Table 1: Verification of WWF low and PLEXOS model [4]

\begin{tabular}{|l|l|l|}
\cline { 2 - 3 } \multicolumn{1}{c|}{} & PLEXOS_WWF low_lower & PLEXOS_WWF low_upper \\
\hline Generation (GWh) & 363898 & 364060 \\
\hline R/a & R 228723737578 & R 252649974601 \\
\hline R/kWh & R 0.63 & R 0.69 \\
\hline $\begin{array}{l}\text { WWF low (lower and upper } \\
\text { bounds) model }\end{array}$ & R 0.44 & R 0.61 \\
\hline Difference & R 0.19 & R 0.08 \\
\hline
\end{tabular}

Since the WWF low model was provided by the modeller, Gauche [8], this was used as a verification of the developed PLEXOS model. The PLEXOS model and results were presented to the WWF modeller, and the results obtained from the developed PLEXOS model were deemed to be within reasonable bounds of the WWF low results.

\section{RESULTS AND DISCUSSION}

The results of the base and constraints can be seen in Error! Reference source not found.. The difference between these two cases accounts for the integration costs. There is an increase in opencycle gas turbines (OCGT) and combined-cycle gas turbines (CCGT) in the constrained case to meet the energy demand, as coal cannot service the demand due to the ramping limits of such a system. As stated before, the PLEXOS model uses day-ahead forecasting, and dispatches according to shortrun marginal costs (SRMC). The emissions were accounted for afterwards, and thus were not part of the dispatch calculation. 
Table 2: Base and constraints summary of system cost elements [4]

\begin{tabular}{|l|l|l|}
\cline { 2 - 3 } \multicolumn{1}{c|}{} & Base & \multicolumn{2}{c|}{ Constraints } \\
\hline Generation costs & R 8 446 billion & R 985 billion \\
\hline Capex & \multicolumn{2}{|c|}{ R 312 billion } \\
\hline Finance & \multicolumn{2}{|c|}{ R 3 380 billion } \\
\hline Total cost & R 10034 billion & R 10042 billion \\
\hline GWh & 406174 & 409819 \\
\hline System cost (R/kWh) & R 0.39 & R 0.48 \\
\hline
\end{tabular}

The capacity factor is the effective use of the generation technology for the allocated time period, and is shown in Figure 7. When the non-renewable generators are constrained, their output decreases noticeably. The RETs' capacity factors remain the same for both cases, since the identical renewable resource data for each generator was used.

Figure 8 then shows the overall RETs' capacity factor expanded for each specific generation technology type. CSP is the highest, with its built-in storage. The fully intermittent technologies of wind and solar PV were closer to industry expected values. Utility PV was placed closer to the highest solar resource, while City PV did not favour the high solar resources, preferring proximity rather than infrastructure. Recalling the research limitations, only utility scale generation plants were considered in the analysis.

Lastly, in Figure 9, the total generation costs were compared against the cost of unserved energy (COUE) for the two cases. The values are a significant order of magnitude different, and thus COUE is negligible.

\subsection{Capex}

Figures 10 and 11 show the capex and interest (Rands) compared with both lifespan and the capacity of the respective plants. New plants show a high capex and interest, while existing plants will show no capex and interest; these were assumed to have been paid off by 2030. Capacity values for each generation technology were set in the respective energy scenarios. Interest for the given plants decreases markedly if the plant has a shorter lifespan. Thus the correlation between capex and interest is seen in Figure 10 and Figure 11.

As discussed above, the details of the capex calculations are captured in Sklar-Chik [4]. The capex and interest calculations were shown to provide a fuller understanding of the total costs for the system, where finance and interest are important costs to be considered.

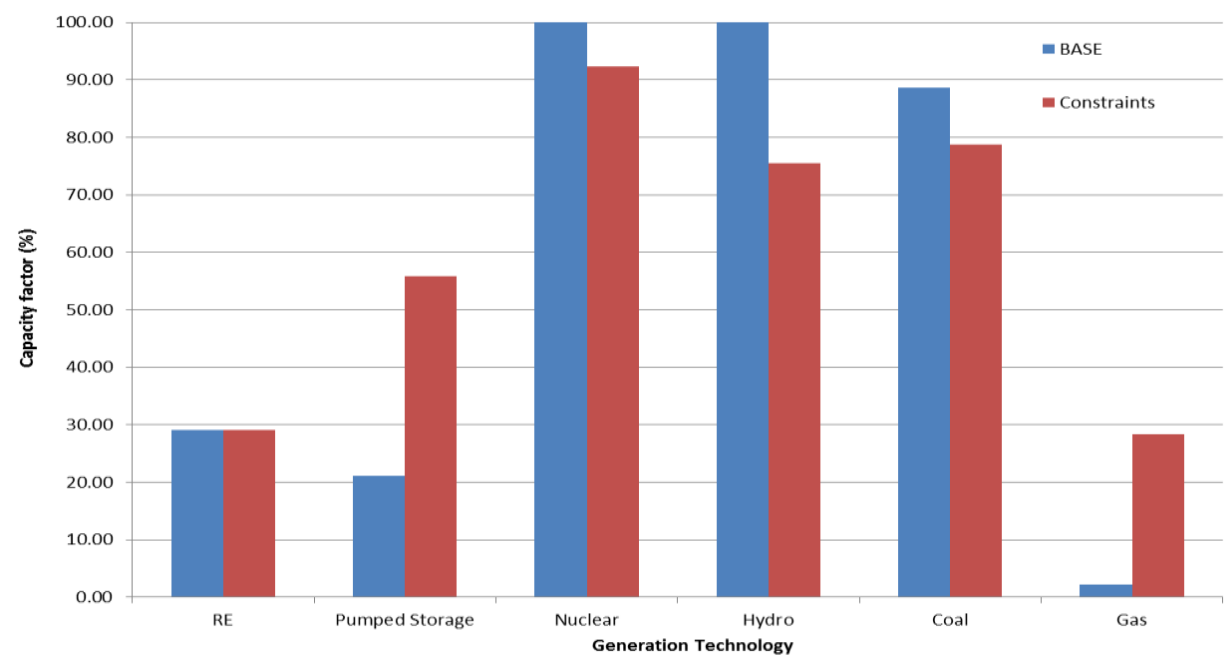

Figure 7: Capacity factors for energy generation technologies(see online version for colour) 


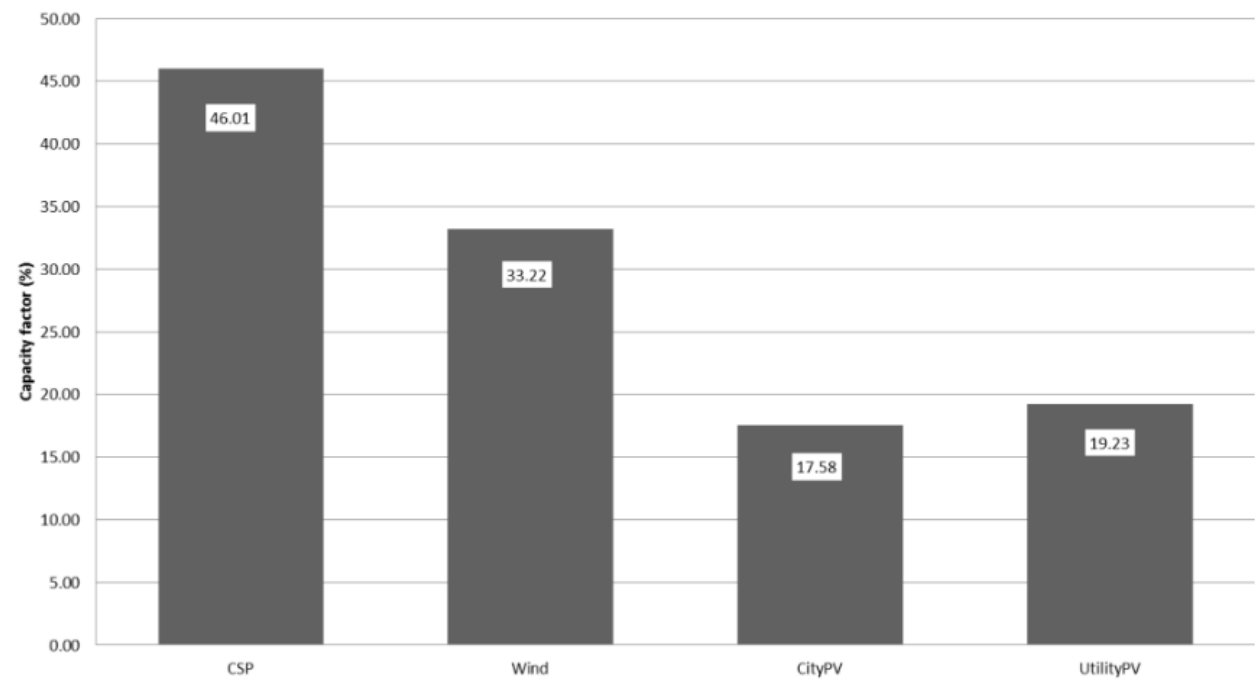

Figure 8: Capacity factors for each renewable generation technology

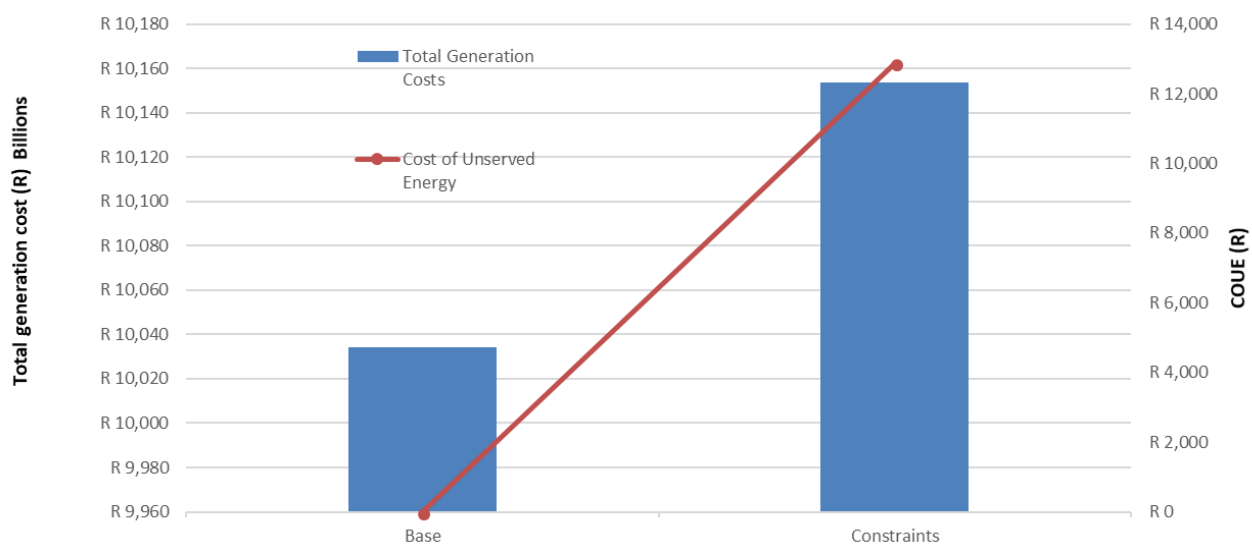

Figure 9: Total generation cost compared against the cost of unserved energy

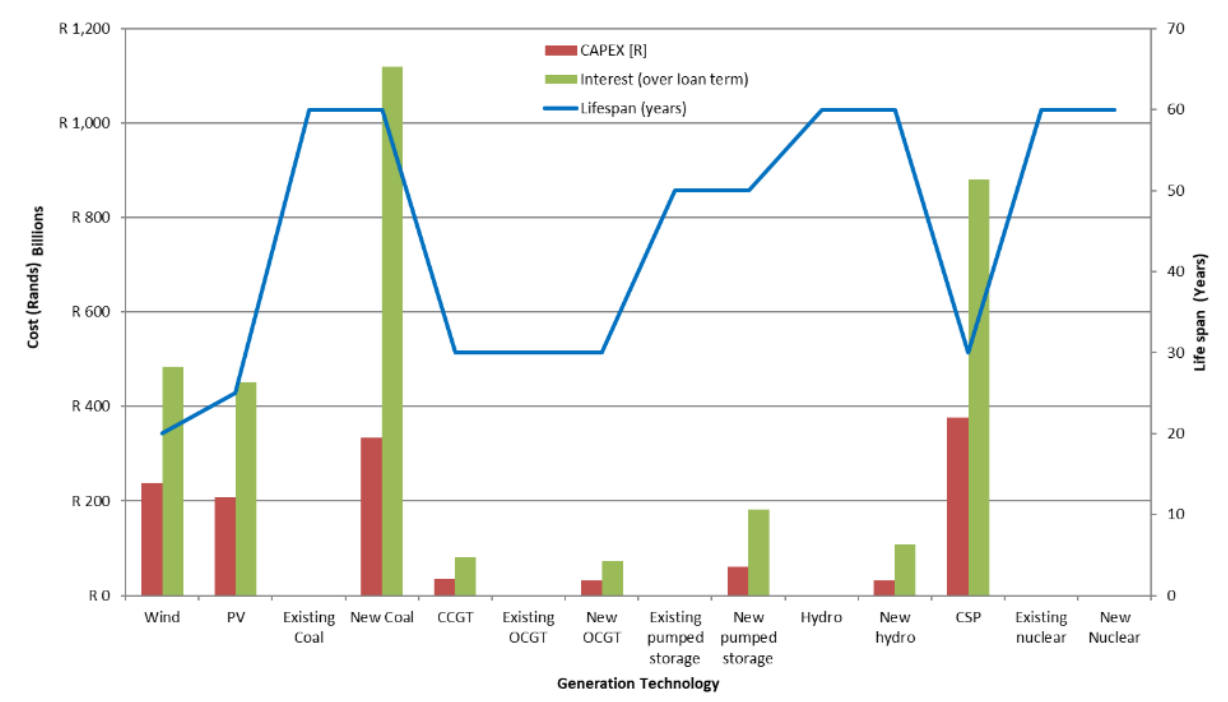

Figure 10: Capex and interest compared with the lifespan of each generation technology (see online version for colour) 


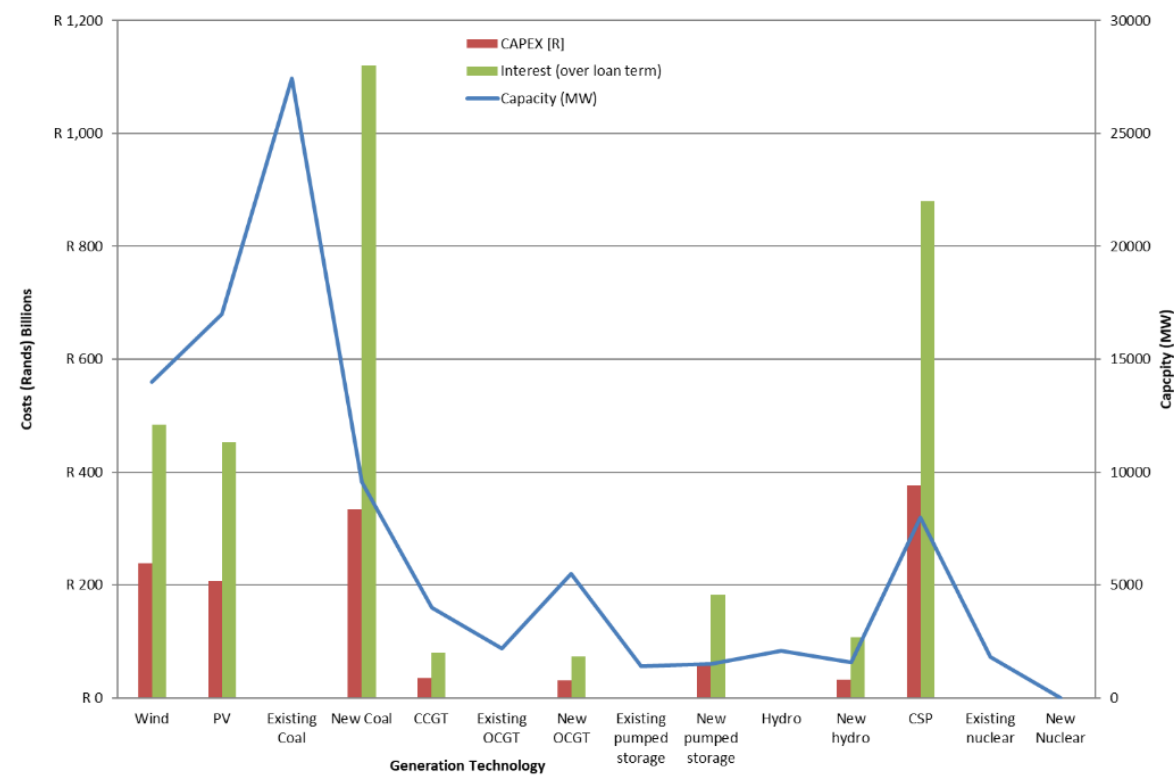

Figure 11: Capex and interest compared with capacity of each generation technology (see online version for colour)

\subsection{Winter week}

The figures were plotted for the highest winter week (12-19 July) of the given load, with the difference of load and generation being the pumped storage scheme values. In the evening, with demand low, the scheme pumped its water from the bottom to the top water reservoir.

Figure 13 shows the aggregated generation per generation technology for the week, and is correlated with Figure 13. These final values will thus be the same.

Marked daily peaks for solar are evident, insofar as the solar resource follows a daily high at midday and drops out completely during the evening. Wind generation is a more unpredictable resource, as seen in the peaks throughout the week. Figure 14 presents the daily trends of the aggregated system output.

For similar summer analysis and results, refer to Sklar-Chik [4].

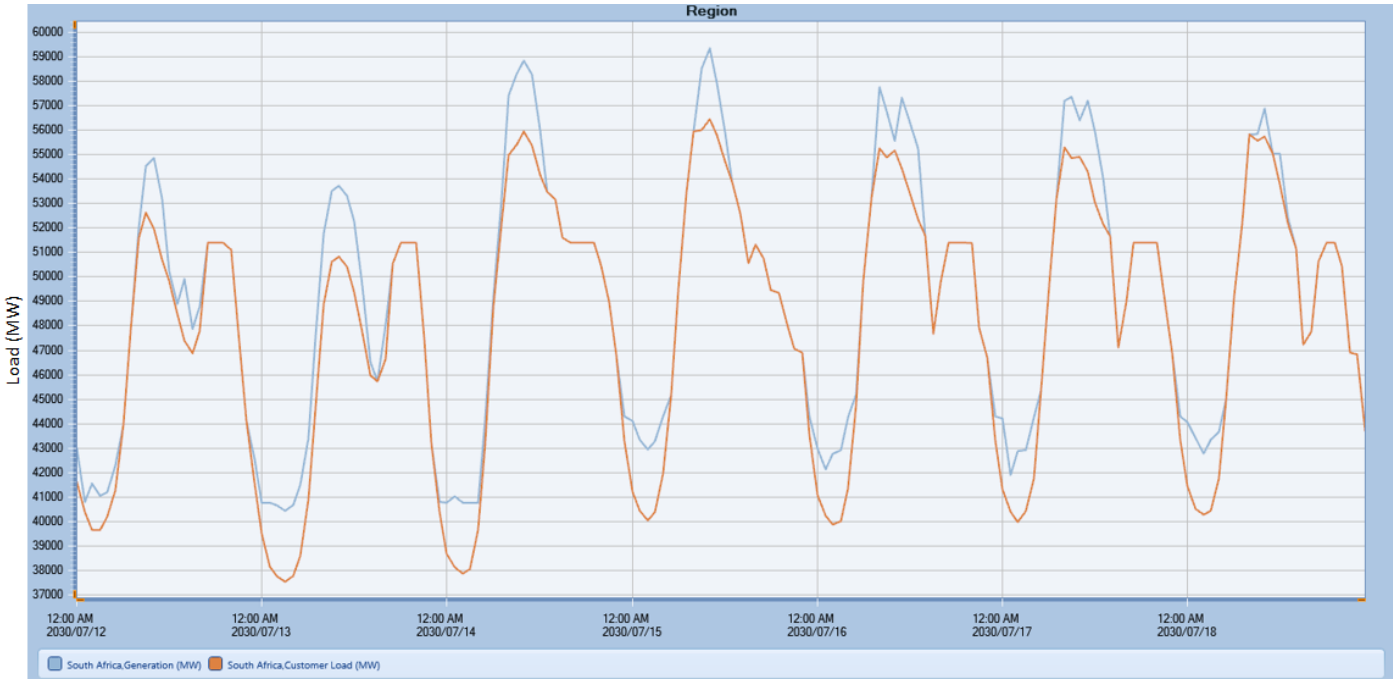

Figure 12: Winter load vs generation profile (see online version for colour) 


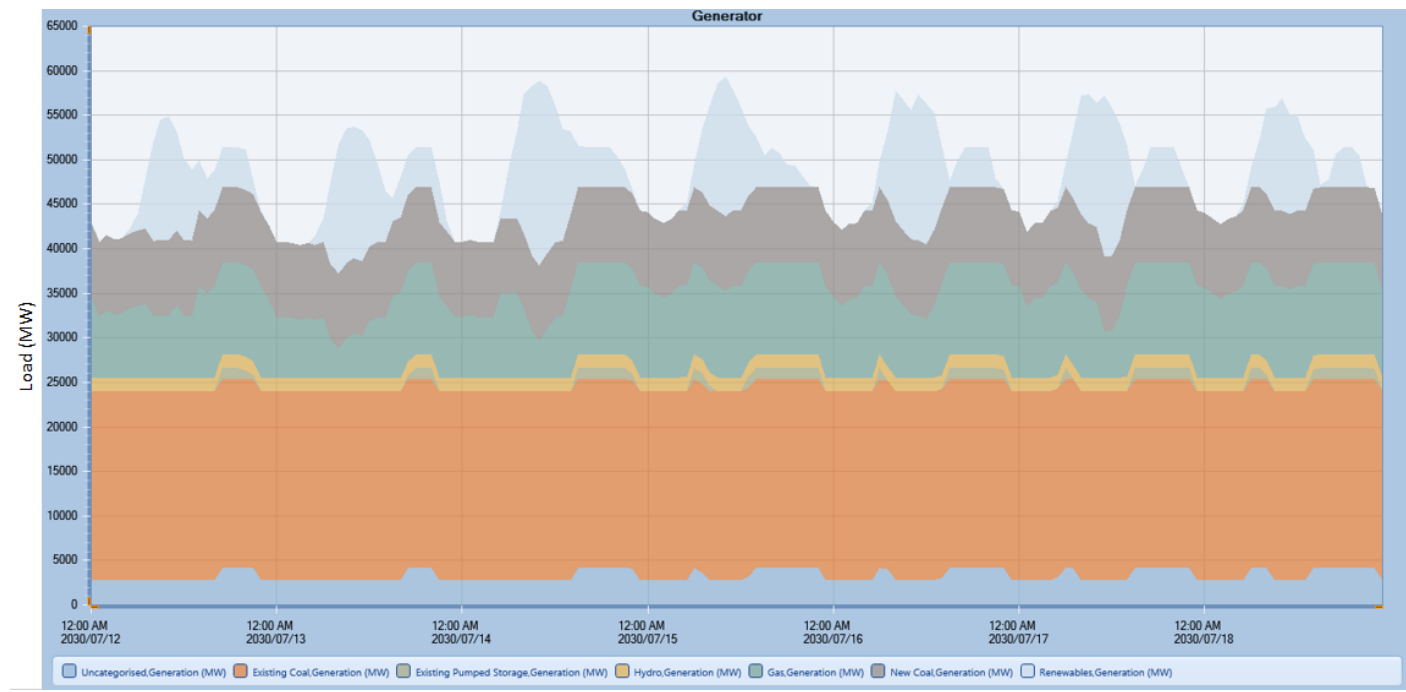

Figure 13: Winter week generation profile: Contribution of each generation technology to supply (see online version for colour)

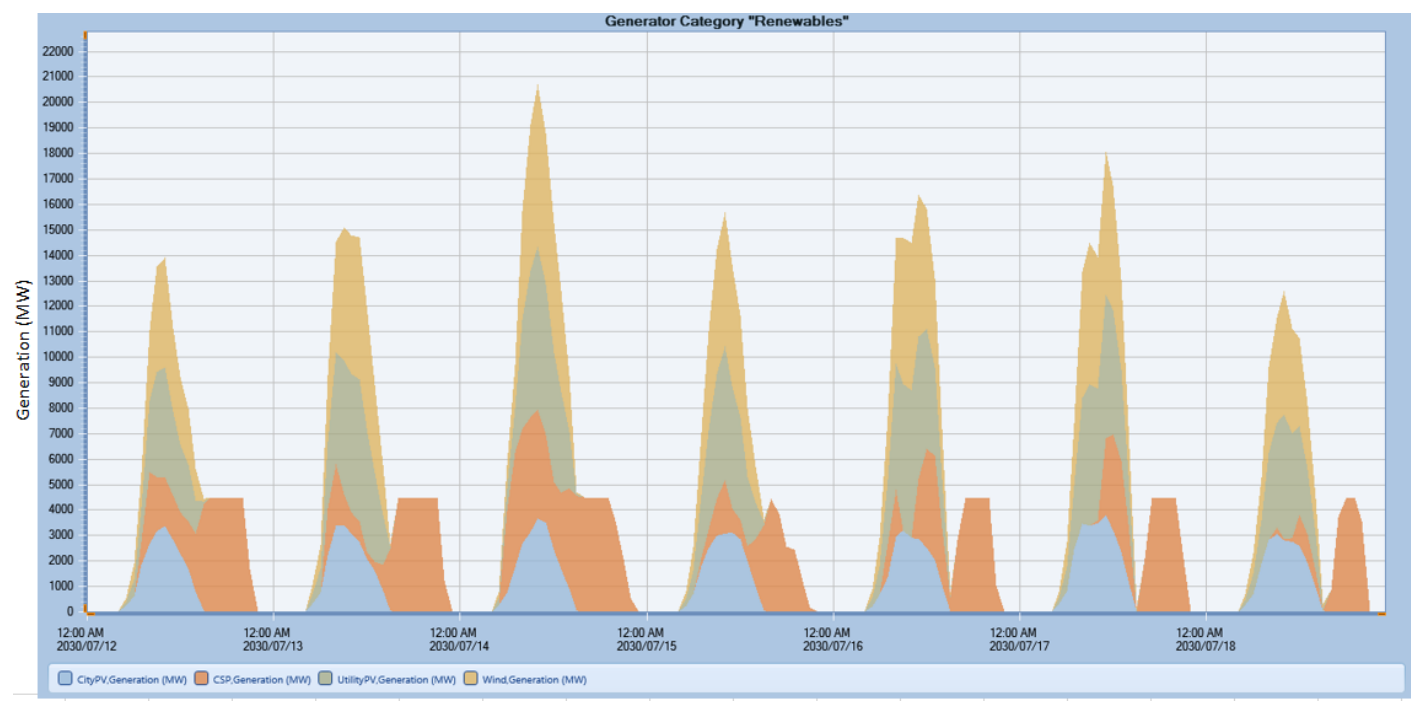

Figure 14: Aggregated winter week renewables output (see online version for colour)

\subsection{Emissions}

Emissions were calculated post-dispatch, and are plotted for both coal and gas technologies. The cost of carbon was R48/ton [10]. Figure 15 describes the tonnes of $\mathrm{CO}_{2}$ emissions for both the base and the constrained cases for the new coal, gas, and existing coal categories of generation technologies.

Figure 16 then depicts the total emissions costs for the base and constrained scenarios. The base scenario has much higher use of coal, and thus more emissions. In the constrained case, gas was used as a peaking generation technology, and so fewer emissions are created per unit energy than with coal generation. 


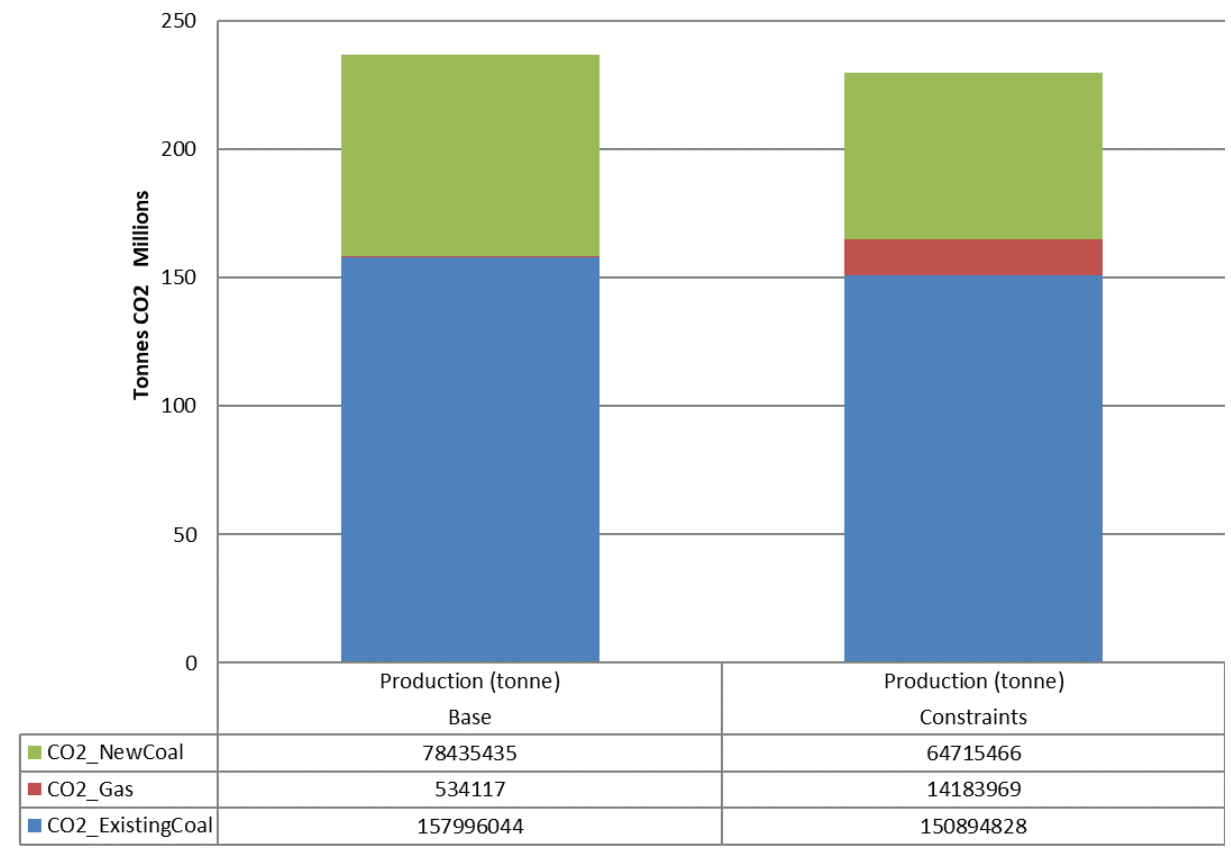

Figure 15: Tonnes $\mathrm{CO}_{2}$ for each scenario (see online version for colour)

\section{R 11.50}

R 11.40

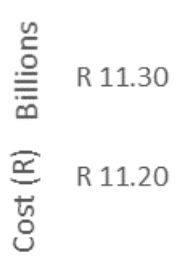

R 11.10

R 11.00

R 10.90

R 10.80

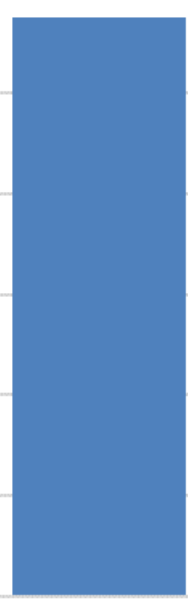

Base

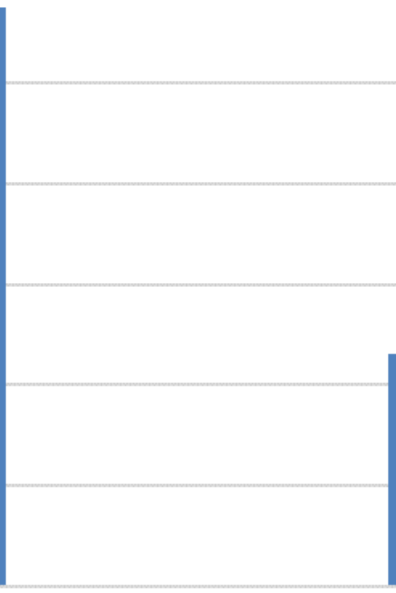

Scenario

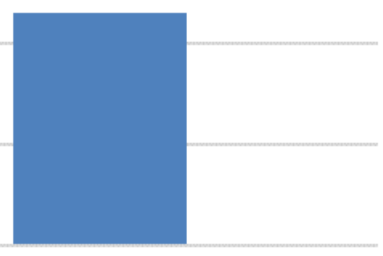

Constraints

Figure 16: Emissions costs per scenario

\subsection{Integration costs}

In what is termed 'integration costs', the unit start-ups and shut-downs and water consumption were computed for both cases. Figure 17 shows the base and constrained cases. Water consumption drops when the number of unit starts and stops decreases, as the non-renewables are shifting to account for the variability of the RETs. 


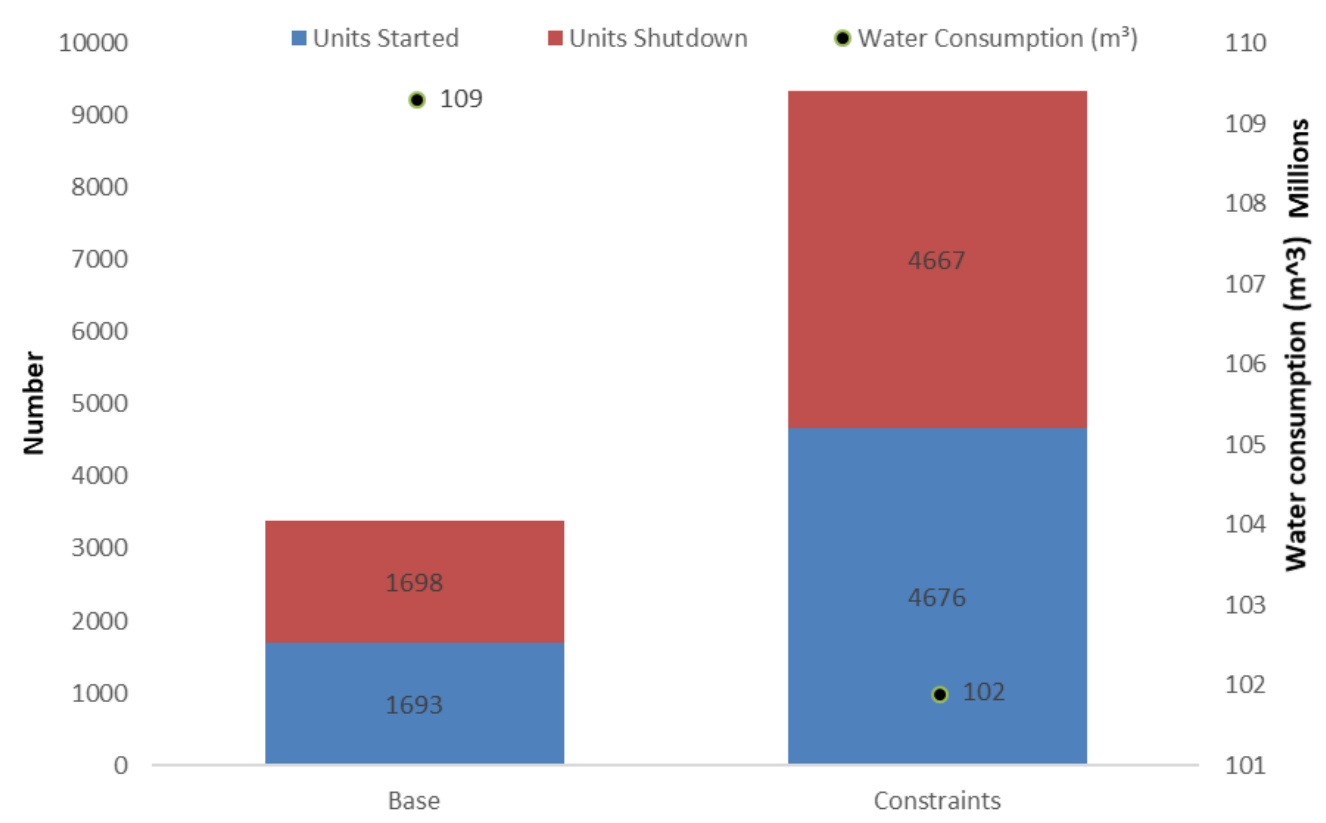

Figure 17: Number of unit start-ups and shut-downs vs water consumption for each case(see online version for colour)

For each generation technology, the corresponding start-ups and shut-downs were plotted in Figure 18. CSP has the largest water requirement of the RETs, while nuclear, in the case of Koeberg ${ }^{4}$, uses abundant sea water for cooling.

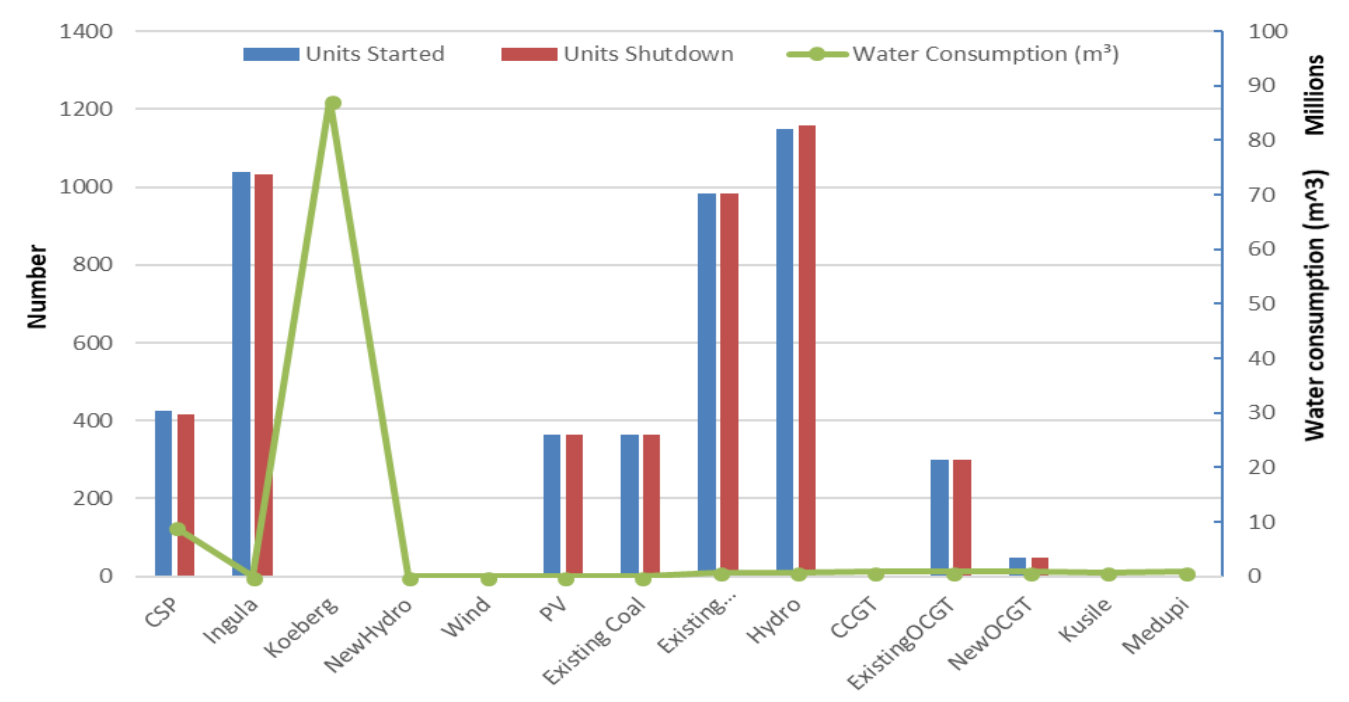

Figure 18: Units started and stopped vs water consumption for each generation technology (see online version for colour)

\subsection{LCOEs for each technology}

Figure 19 depicts the LCOE for each generation technology for the base and constrained cases respectively. When the constraints are applied to the generators, costs decrease considerably, since the amount of energy produced by gas increases [4]. In the constrained scenario, gas production increased, while the coal production decreased [4].

4 Koeberg is South Africa's only nuclear power station. It is located in the Western Cape coastal region, and consists of two reactors. 


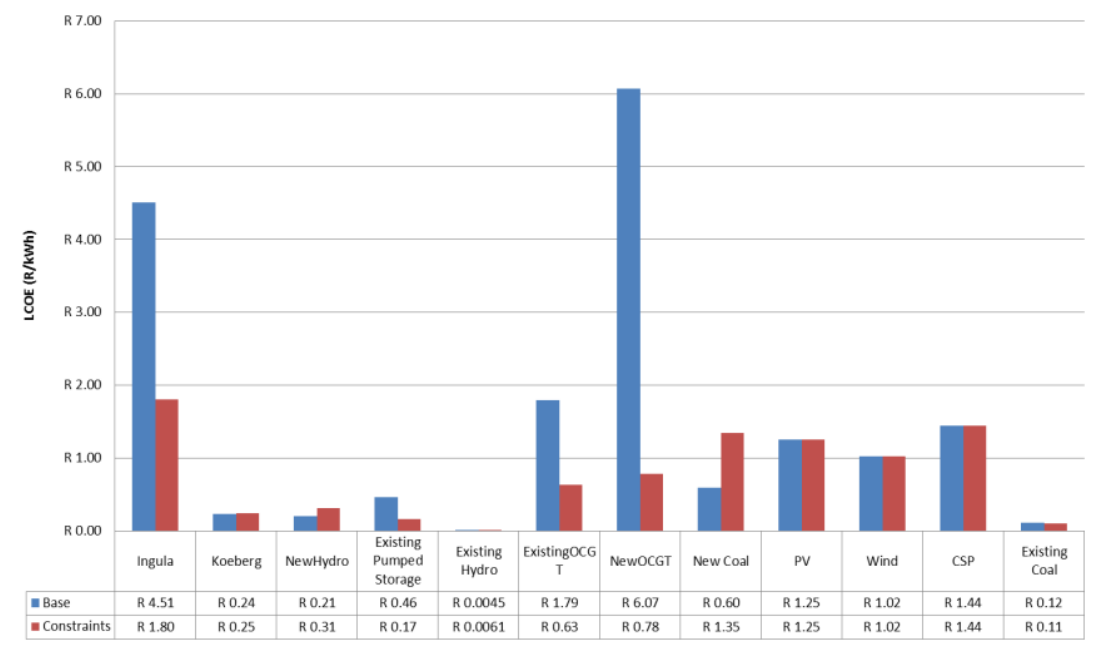

Figure 19: LCOE comparison of base and constrained cases (see online version for colour)

\subsection{Sensitivity analysis}

Figure 20 presents the system capacity factor for each sensitivity analysis. When electricity demand decreases to WWF low values, the capacity factor (CF) decreases to well below 40 per cent. The other sensitivity cases have a smaller impact on the CF.

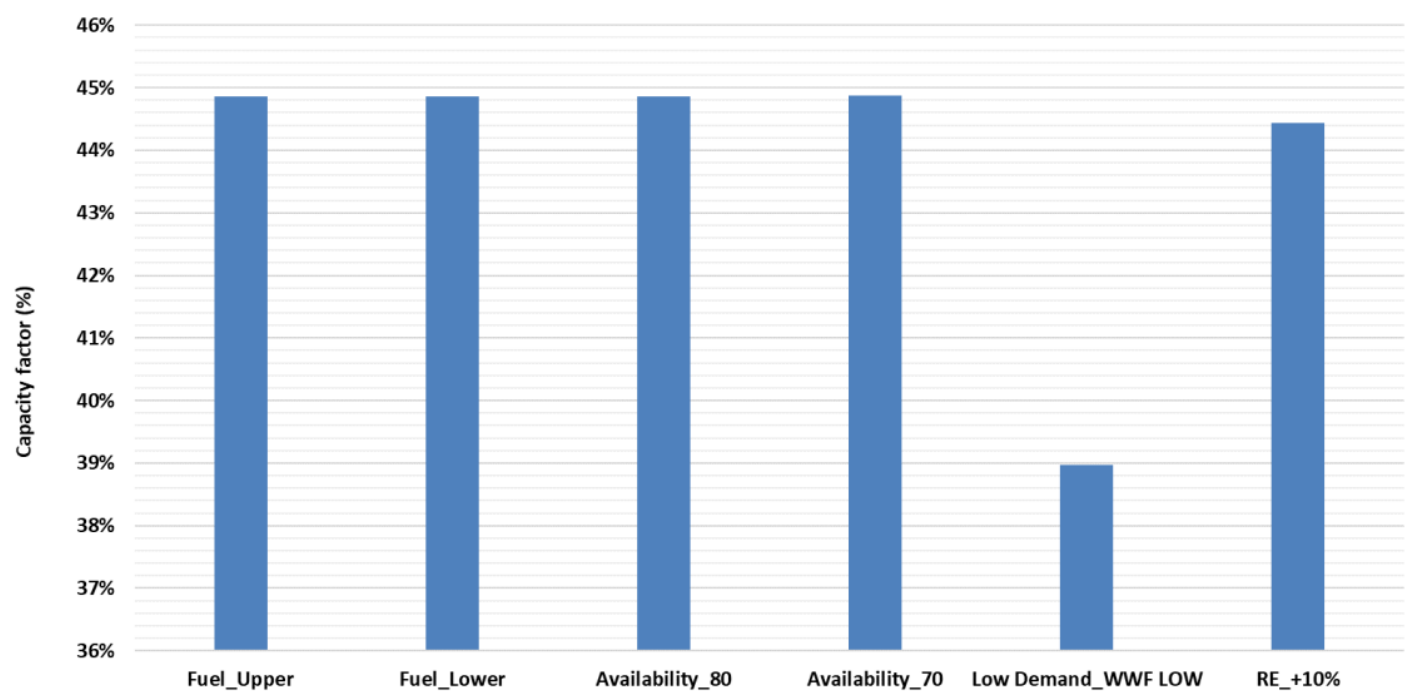

Figure 20: Overall capacity factor for each sensitivity case

Figure 21 illustrates the system costs for each sensitivity scenario, and then compares these values with the constrained case on the secondary axes. Again, the highest impact on system costs is a change in the demand for electricity.

From the sensitivity analysis, the change in electricity demand forecast is seen to influence the model outputs substantially. This is within reason, since the system cannot change its installed capacity when demand decreases, and thus the coal, gas and nuclear generation technologies become poorly used. The other parameters have less influence on the output costs than changing demand. 


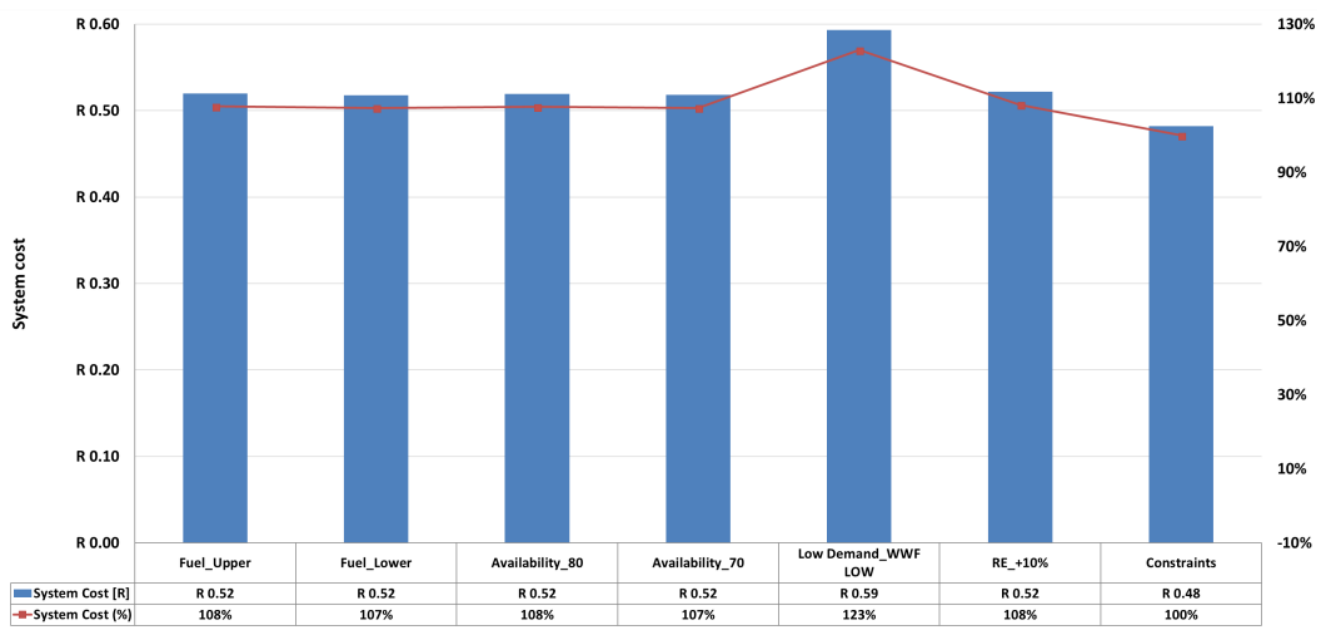

Figure 21: System costs of each sensitivity scenario

\section{CONCLUSIONS}

This paper provides details of the integration costs of renewables in future electricity scenarios. The costs were not significant at lower RET penetration levels. In addition to the integration costs, LCOEs were computed for typical renewables and non-renewable technologies. A summary of the key results is presented in Table 3.

Table 3: Summary of results for base and constrained cases

\begin{tabular}{|c|c|c|}
\hline & Base & Constraints \\
\hline Generation costs & R 8446 billion & R 9085 billion \\
\hline Capex & \multicolumn{2}{|c|}{ R 1312 billion } \\
\hline Finance & \multicolumn{2}{|c|}{ R 3380 billion } \\
\hline Total cost & R 10034 billion & R 10042 billion \\
\hline GWh & 406174 & 409819 \\
\hline System cost (R/kWh) & R 0.39 & R 0.48 \\
\hline
\end{tabular}

A number of recommendations should be considered for future research. These include: a multimodal network with transmission and distribution lines, maintenance events (outages, etc.), renewables production using detailed solar and wind resource data, most recent costing data (IRP 2016, etc.), updating demand forecasts, non-utility scale projects (embedded generation, smallIPPs, etc.), further integration elements and costs, technology variation and detail (within PV there are different types), benchmark financial parameters, and emissions costing in the dispatch of generation.

\section{REFERENCES}

[1] Sager, M. 2014. Renewable energy vision 2030 - South Africa. World Wildlife Fund, report available from: http://awsassets.wwf.org.za/downloads/a16369_wwf_reip_report_online.pdf

[2] Walwyn, D.R. \& Brent, A.C. 2015. Renewable energy gathers steam in South Africa, Renew. Sustain. Energy Rev., 41, pp. 390-401.

[3] Sklar-Chik, M.D., Brent, A.C. \& De Kock, I.H. 2016. Critical review of the levelised cost of energy metric, South African J. Ind. Eng., 27(4), pp. 124-133.

[4] Sklar-Chik, M.D. 2017. System cost of energy generation scenarios for South Africa: Understanding the real cost of integrating energy generation technologies. Masters thesis, Department of Industrial Engineering, Stellenbosch University, available from: http://hdl.handle.net/10019.1/100811.

[5] Hirth, L., Ueckerdt, F. \& Edenhofer, O. 2015. Integration costs revisited: An economic framework for wind and solar variability, Renew. Energy, 74, pp. 925-939.

[6] Pöller, M., Ober, M. \& Moodley, G. 2015. Analysis of options for the future allocation of PV farms in South Africa. Deutsche Gesellschaft für Internationale Zusammenarbeit (GIZ), available from: http://pqrs.co.za/wp-content/uploads/2015/03/GIZ-M.P.E.-2015-Analysis-of-options-for-the-futureallocation-of-PV-farms-in-South-Africa-FINAL-REPORT.pdf.

[7] Ueckerdt, F., Hirth, L., Luderer, G. \& Edenhofer, O. 2013. System LCOE: What are the costs of variable renewables?, Energy, 63, pp. 61-75. 
[8] Gauché, P. 2015. Feasibility of the WWF renewable energy vision 2030 - South Africa. World Wildlife Fund, report available from: http://www. wasaproject.info/docs/WWFREVision2030Jul2015.pdf

[9] Connolly, D., Lund, H., Mathiesen, B.V. \& Leahy, M. 2010. A review of computer tools for analysing the integration of renewable energy into various energy systems, Appl. Energy, 87(4), pp. 1059-1082.

[10] DoE. 2011. Integrated resource plan for electricity 2010-2030, Pretoria: Department of Energy

[11] WWF. 2014. Enabling renewable energy in South Africa: Assessing the renewable energy independent power producer, World Wildlife Fund, report available from:

http://awsassets.wwf.org.za/downloads/enabling_re_in_sa.pdf. 